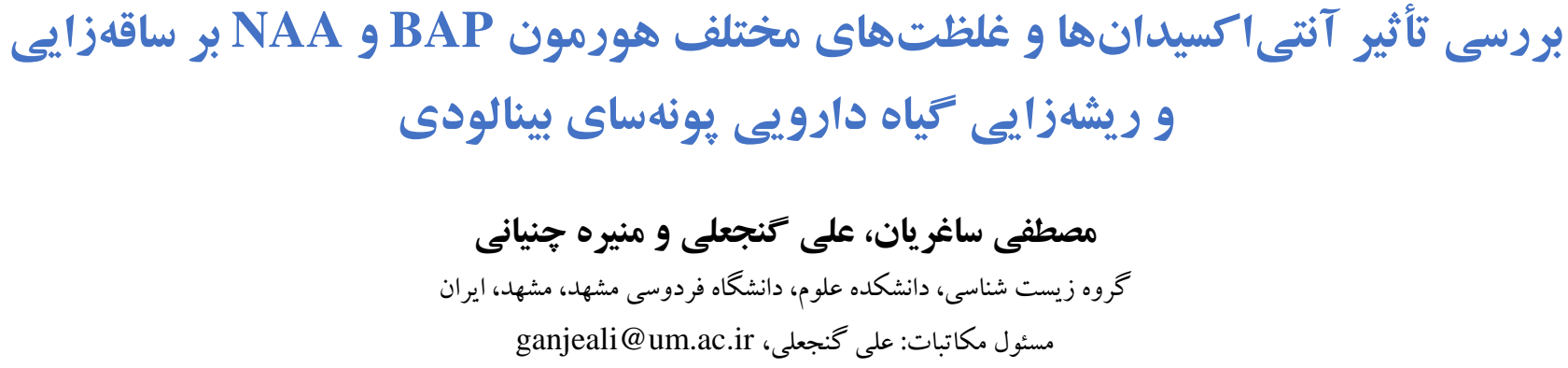

\title{
Investigating the effect of antioxidant compounds and various concentrations of BAP and NAA on the improvement of in vitro stem and root formation of Nepeta binaloudensis Jamzad
}

\author{
Mostafa Sagharyan, Ali Ganjeali \& Monireh Cheniany \\ Department of Biology, Faculty of Science, Ferdowsi University of Mashhad, Mashhad, Iran. \\ Correspondent author: Ali Ganjeali, ganjeali@um.ac.ir
}

\begin{abstract}
Nepeta binaloudensis Jamzad is a medicinal plant endemic to Iran. It is an endangered plant due to habitat destruction and intensive harvest. We investigated the effect of antioxidants and different concentrations of BAP and NAA on in vitro stem and root formation of $N$. binaloudensis. Stem explants were cultured in $1 / 2$ MS medium supplemented with BAP $(0.5 \mathrm{mg} / \mathrm{L})$ and different concentrations of ascorbic acid and reduced glutathione. The effect of different concentrations of BAP on the regeneration of this plant was then evaluated. Moreover, root formation of regenerated stems was investigated in the $1 / 2$ MS medium supplemented with different concentrations of NAA. The results showed that the combination of antioxidants in $1 / 2$ MS medium supplemented with BAP $(0.5 \mathrm{mg} / \mathrm{L})$ had a significant effect on regeneration in vitro culture. The reduced-glutathione $(2 \mu \mathrm{M} / \mathrm{L})$ in comparison with other antioxidant treatments increased the stem regeneration in explants. The levels of BAP hormone (1 and $1.5 \mathrm{mg} / \mathrm{L})$ had a significant ( $\mathrm{p}$-value $<0.05)$ effect on the stem regeneration rate and the number of produced branches. The NAA (2 $\mathrm{mg} / \mathrm{L}$ ) increased root formation and root height average. We recommend the use of these treatments for in vitro propagation of this endangered plant.
\end{abstract}

Keywords. culture medium, growth optimization, in vitro culture, Lamiaceae, shoot proliferation 
دست آمده است (Arikat et al., 2004). بهترين محيط ساقه-

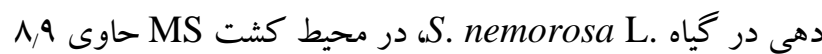
ميكرومول بر ليتر BA و Y, ميكرومول بر ليتر IAA بوده است و

همجنين بهترين محيط ريشهدهى محيط MS، حاوى هر. مkala \& ) معرفى شده است NAA ميكول بر ليتر L. Wysokinsca, 2006 Lavendula dentana MS ريشهدهى محيط كشت MS حاوى Y ميلى گرم بر ليتر هورمون

Andrade \& Basso, 2005) معرفى شده است NAA

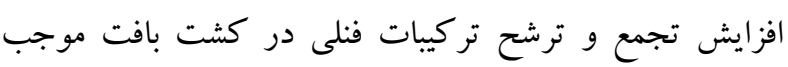

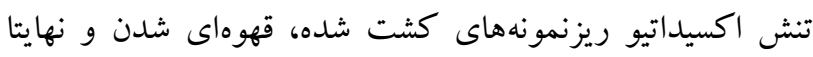

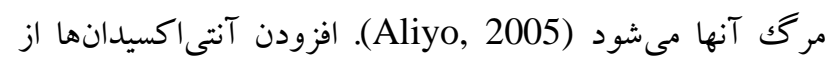

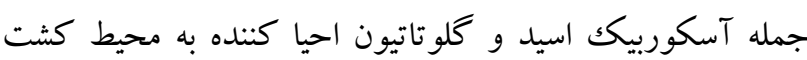
موجب ايجاد شرايط احيايى مى شود كه علاوه بر كاهش قهوهاى شدن ناشى از تنش اكسيداتيو، باعث افزايش سرعت ساقزايى و

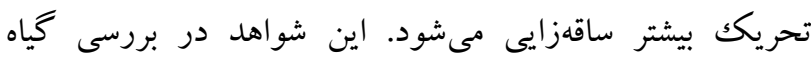
و Nomura ،(Joy et al., 1998) Nicotiana tabacum L. گياه ( Nomura et al., 1998) Malus pumila Milla Dutta Gupta \& ) Gladiolus $\times$ hybridus C.Morren (Datta, 2003 با توجه به موارد اشاره شده، آزمايش حاضر با هدف بررسى امكان

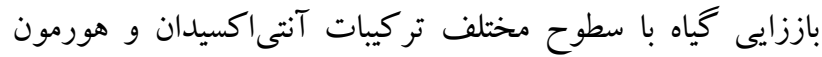
هاى BAP و BAA در شرايط درون شيشه انجام شده است.

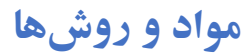

بذرهاى گياه يونهاى بينالودى از هرباريوم دانشكاه فردوسى مشهد

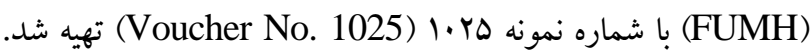
اين بذرها با استفاده از مواد شوينده، آب مقطر و آب زاول ماول استريل شدند. در نهايت، بذرهاى استريل شده درون بترى ديش هاى استريل

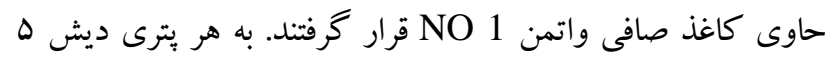

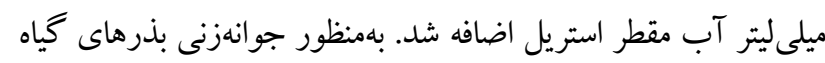

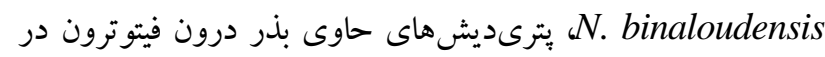

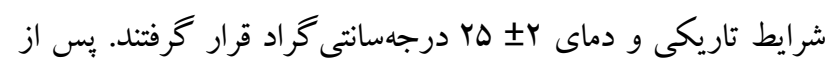

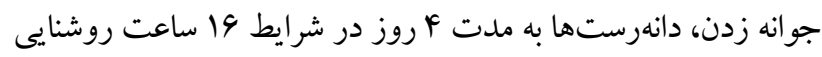

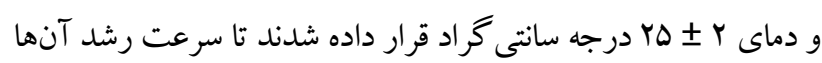

مقلفمه

كياهان دارويى منابعى هستند كه نقش مهمى در سيستم درمانى جهان برعهده دارند. به گونه اي كه حدود ·V الى ·N درصد مردم جهان براى تأمين نيازهاى درمانى خود از گياهان دارويى استفاده

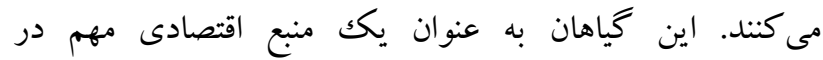
كشورهاى توسعه يافته مورد استفاده قرار مى گيرند (Pei, 2001). سرده Nepeta از تيره نعنائيان (Lamiaceae) شامل •هr كونه يكك ساله و جندساله است كه در نقاط مختلف آسيا، ارويا و شمال

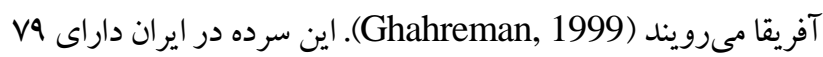

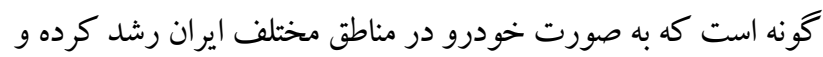

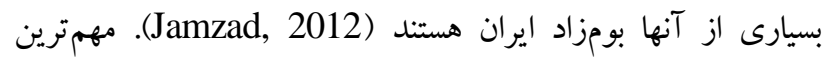
تركيات موجود در اسانس گونههاى مختلف سرده Nepeta

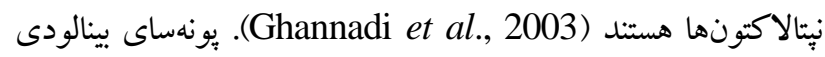
گ گياهى بومى، جند ساله و كمياب (N. binaloudensis Jamzad) است كه در رشته كوههاى بينالود در استان خراسان رضوى، در

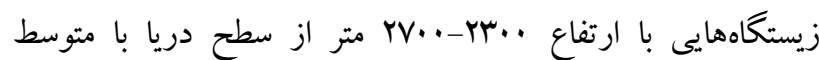

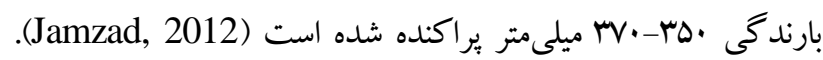
اين گياه در طب سنتى كشور به عنوان مدر، معرق، ضماد زخم، ضد سرفه، ضد اسباسم، انرزىزا، تب بر و آرام بخش مورد استفاده قرار

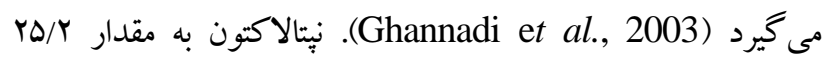

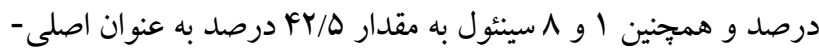
ترين تركيبات موجود در اسانس بخش هاى هوايى اين گياه گزارش شده اند (Rustaiyan \& Nadji, 1999). تكثير گونههاى Lamiaceae از طريق كاشت بذر بهدليل توليد كم بذر و نرخ بايين جوانهزنى با مشكل مواجه است ك. Sulistiarini, 1999) برداشت بىرويه، تكثير كند و درصد جوانهزنى بايين بذور اين گياه

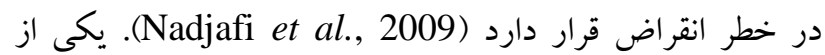
روشهاى حفاظت گياهان در معرض خطر انقراض، ريزازديادى آنهاست (Modarres et al., 2012). محققان به بررسى ريزازديادى در سردههاى مختلف از تيره نعنائيان برداختهاند. به

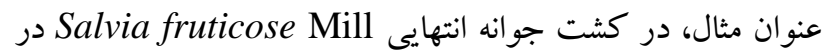

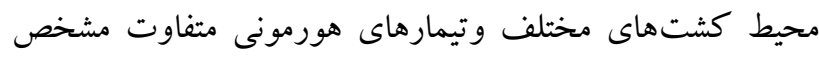

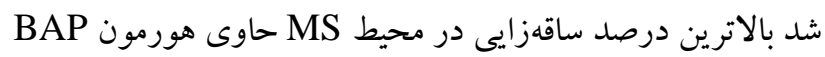

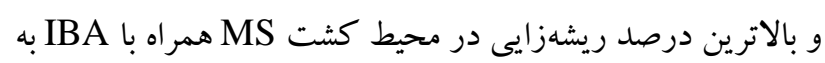


آزمايش سوم با هدف بررسى تأثير غلظت هاى مختلف هورمون NAA

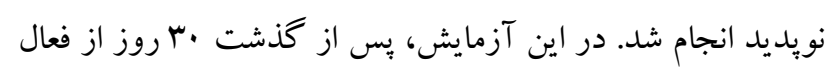

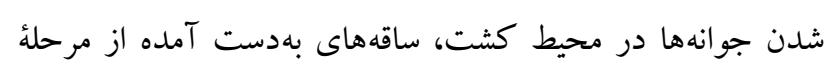

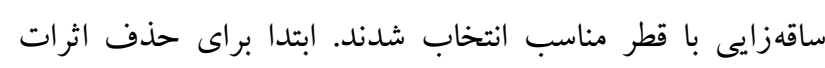

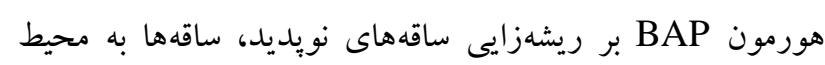

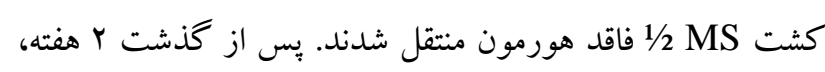

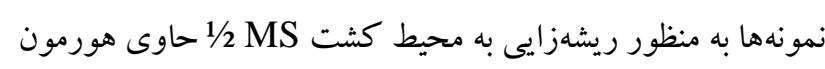

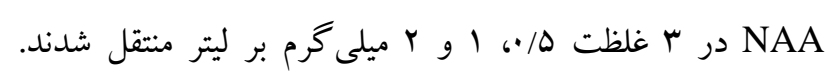
درصد ريشهزايى و ميانگين طول ريشهها (به ازاى هر نمونه) بعد از

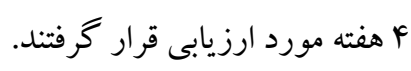

صفات مورد بررسى مورد

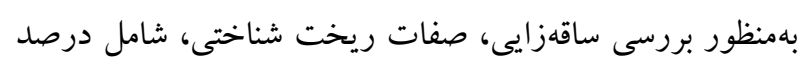

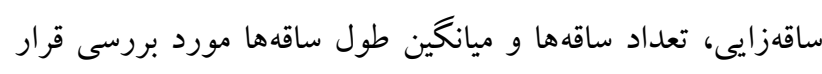
كرفتند. درصد ساقهزايى از طريق معادله زير محاسبه شد:

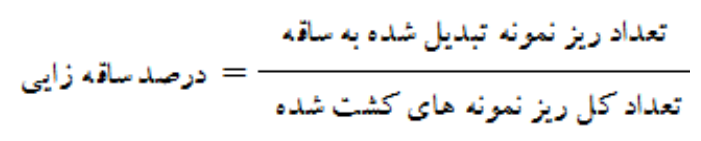

درصد ريشهزايى طبق معادله زير محاسبه شد:

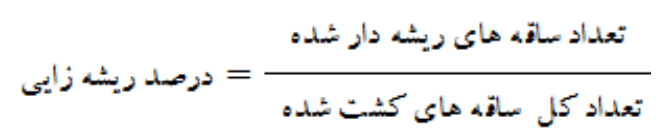

\section{تحليل آمارى}

همه آزمايشها دمارى قالب طرح كاملا تصادفى و با ب تكرار انجام شد

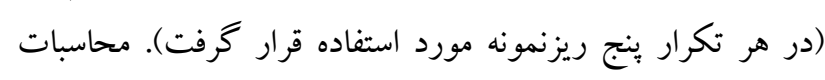

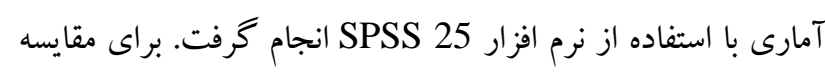

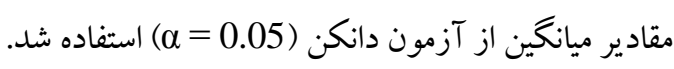

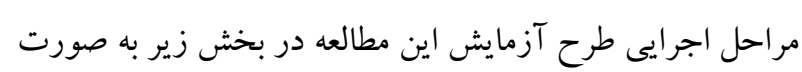
شماتيك آورده شده است (شكل ()).

نتانج

\section{آزمايش اول}

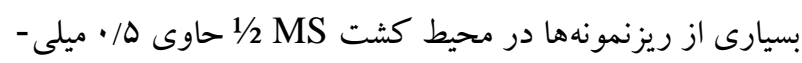

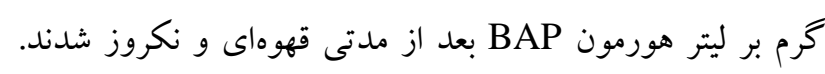

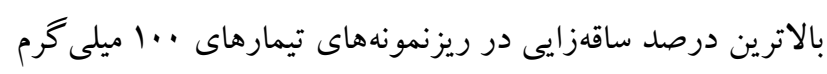

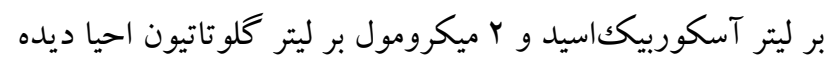

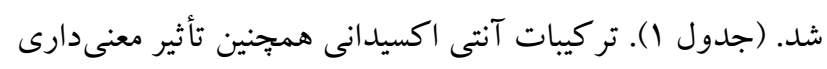

بيشتر شود. در انتها، دانهرستها براى توليد گياه مادر به محيط Arnon \& Hoagland, ) هيدرويونيك حاوى محلول غذايى هو كلند 1940) منتقل شده و در اتاقكك رشد قرار گرفتند. گياه مادر در شرايط مايط

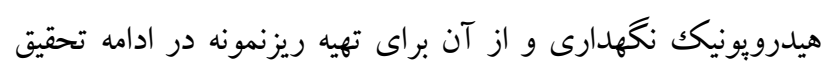
استفاده شد.

\section{محيط كثت و ريزنمونهها}

به منظور بررسى ساقهزايى گياه، از ريزنمونه ساقه گياه مادرى ونمان

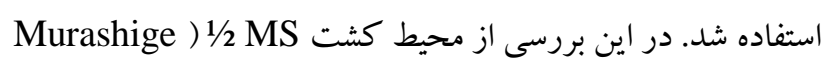
V) (\& Skoog, 1962

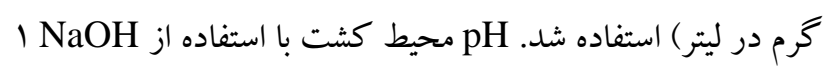

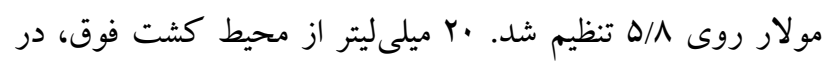

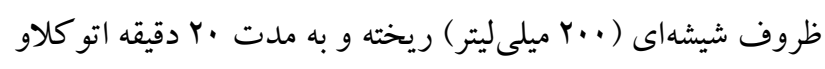

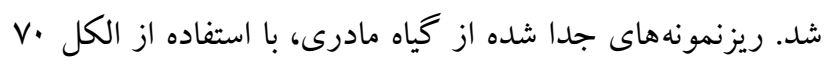

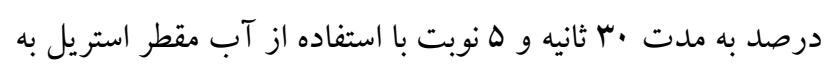

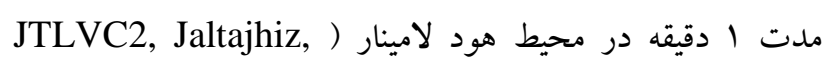

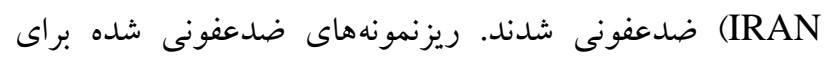

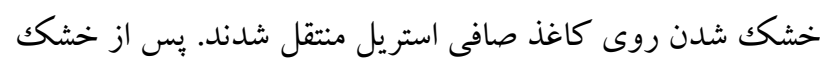

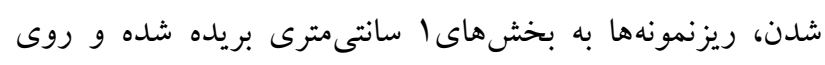

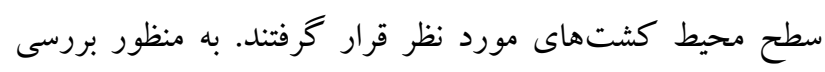

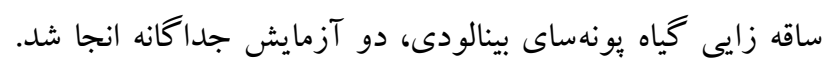
در آزمايش اول، تاثير غلظتهاى مختلف آسكوربيك اسيد (...

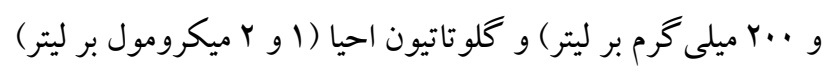

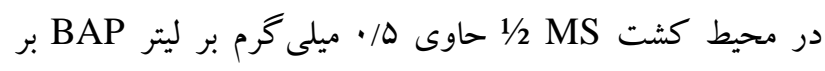

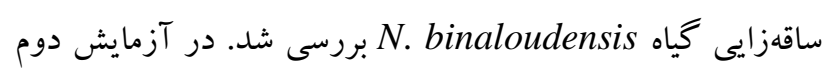

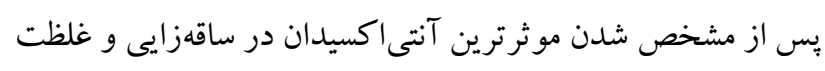

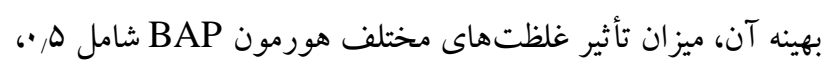

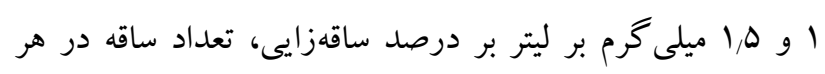

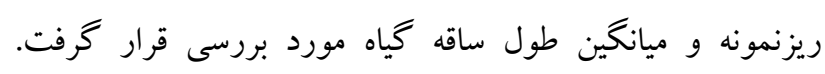

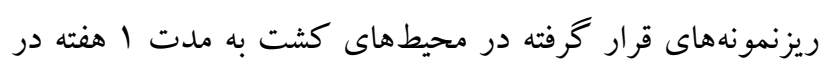

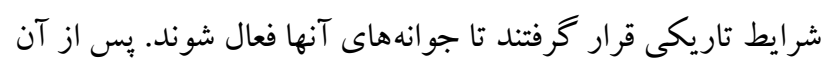

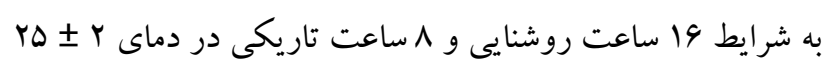

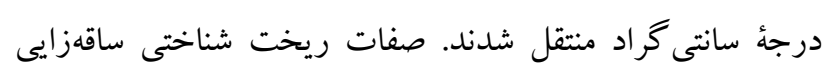

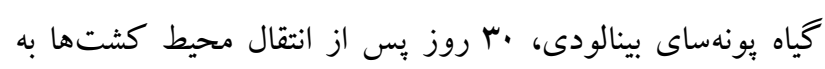

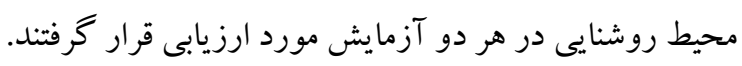




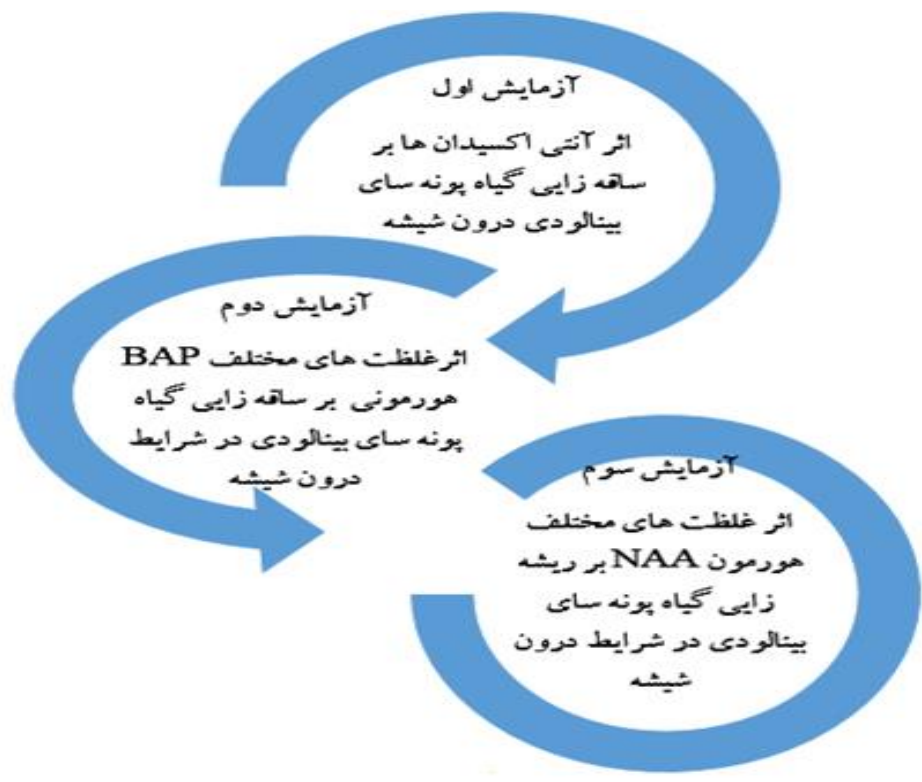

شكل ا - نمودار شماتيك از مراحل اجرايى طرح آزمايش در مطالعه ساقهزايى و ريشهزايى گياه يونه ساى بينالودى در شرايط درون شيشه.

Fig. 1. The schematic chart of the stages of the experimental design in the study of regeneration and root formation of $N$. binaloudensis in vitro condition.

جدول ا- آزمون مقايسه ميانگين هاى جند گانه دانكن برروى صفات ريخت شناختى ساقهاى گياه بونهاى بينالودى در تيمارهاى مختلف آنتى اكسيدانى.

Table 1. Comparison of Duncan multiple means on some morphological traits of plant stems in N. binaloudensis at different antioxidant treatments.

\begin{tabular}{|c|c|c|c|}
\hline \multicolumn{3}{|c|}{ صفات ريزازديادى } & \multirow{2}{*}{ نوع و غلظت تركيبات آنتى اكسيدانها } \\
\hline طول ساقهها (cm) & تعداد ساقهزايى (به ازاى ريزنمونه) & درصد ساقهزايى & \\
\hline $1, \Delta \pm \cdot, v a F^{n s}$ & $r, q \mathrm{~V} \pm \cdot \Delta \mathrm{W}^{\mathrm{d}}$ & $r \cdot b$ & 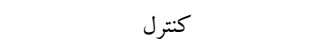 \\
\hline $1,9 \mathrm{~V} \pm \cdot, r \mathrm{Vq}^{\mathrm{ns}}$ & $r, \pi \pm 1,10 \Delta^{\mathrm{d}}$ & 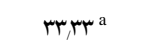 & Asc $100 \mathrm{mg} / \mathrm{L}$ \\
\hline $1, \lambda f \pm \cdot r^{n s}$ & $1,9 \vee \pm 1,100^{b}$ & $r \cdot b$ & Asc $200 \mathrm{mg} / \mathrm{L}$ \\
\hline $1, \lambda \cdot \pm \cdot v \Delta \Delta^{\mathrm{ns}}$ & $\Delta, r r \pm 1,1 \Delta \Delta^{c}$ & $r \cdot{ }^{b}$ & Reduced-glu $1 \mu \mathrm{M} / \mathrm{L}$ \\
\hline$r, K^{f} \pm \cdot r \cdot r^{n s}$ & $1.90 \pm 1,1000^{\mathrm{a}}$ & $\mathrm{f} \cdot{ }^{\mathrm{a}}$ & Reduced-glu $2 \mu \mathrm{M} / \mathrm{L}$ \\
\hline
\end{tabular}

ستونهاى واجد حروف مشترك، در سطح احتمال (p-value (p) 0.05 تفاوت معنى دارى ندارند.

There is no significant difference among those columns that have same letter.

نتايج تجزيه واريانس دادهها نشان داد كه، غلظتهاى مختلف هورمون BAP تأثير معنىدارى بر درصد ساقهزايى ، تعداد ساقه و طول ساقه داشتند (جدول Y). غلظت هاى مختلف هورمون BAP همجنين تأثير معنىدارى بر درصد ساقهزايى، تعداد ساقهها و طول ساقه داشتند (p-value > 0.05). بيشترين درصد ساقهزايى، تعداد ساقه و طول ساقهها با مقادير ·9 درصد، 19 (تعداد ساقه ايجاد شده به ازاى هر ريزنمونه) و هارب سانتىمتر به تيمار هرا ميلى گرم بر ليتر هورمون BAP مربوط بود كه تفاوت آن با ساير سطوح (p-value s0.05) مقدار 1, 9V 1 (تعداد ساقه ايجاد شده به ازاى هر ريزنمونه) به تيمار

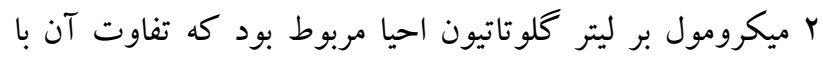
ساير تيمارهاى تحت بررسى و شاهد معنىدار بود (جدول ()). در اين آزمايش بررسى نتايج تأثير نوع و غلظتهاى مختلف آنتى -

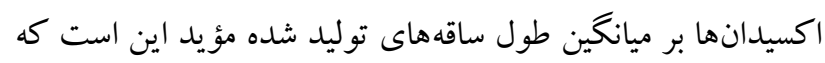
آنتى اكسيدانها اثر معنىدارى بر طول ساقه ها ندارند (جدول ().

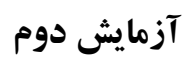


جدول r- آزمون مقايسه ميانگين هاى جند گانه دانكن بر روى برخى صفات ريخت شناختى ساقهاى گياه يونه ساى بينالودى در غلظتهاى مختلف هورمون BAP

Table 2. Comparison of Duncan multiple means on some morphological traits of plant stems in N. binaloudensis at different concentrations of BAP hormone.

\begin{tabular}{|c|c|c|c|}
\hline \multicolumn{3}{|c|}{ صفات ريزازديادى } & \multirow{2}{*}{ 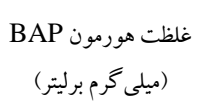 } \\
\hline طول ساقه (cm) & تعداد ساقه (به ازاى ريزنمونه) & درصد ريزازديادى & \\
\hline$r, \mu e^{b}$ & $1.9 \mathrm{~V}^{\mathrm{b}}$ & r. b & $\cdot / \Delta$ \\
\hline$r, F^{b}$ & $v, g V^{c}$ & $\Delta r, r r^{a}$ & 1 \\
\hline$r, \kappa_{\Delta}{ }^{a}$ & $19^{\mathrm{a}}$ & $4 \cdot{ }^{a}$ & $1 / 0$ \\
\hline
\end{tabular}

ستو نهاى واجد حروف مشتر ك،، در سطح احتمال (p-value (p) تفاوت معنىدارى ندارند.

There is no significant difference among those columns that have same letter.

جدول با- آزمون مقايسه ميانكينهاى جند گانه دانكن بر روى برخى صفات ريخت شناختى ريشهزايى در گياه بونهاى بينالودى در غلظتهاى مختلف هورمون .NAA

Table 3. Comparison of Duncan multiple means on some morphological traits of rooting in N. binaloudensis at different concentrations of NAA hormone.

\begin{tabular}{|c|c|c|}
\hline \multicolumn{2}{|c|}{ ״يارامترهاى ريزازديادى } & \multirow{2}{*}{ 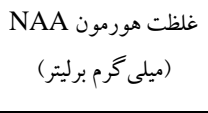 } \\
\hline طول ريشه (cm) & درصد ريشهزايى & \\
\hline$\cdot 9 F^{c}$ & ( & $\cdot / \Delta$ \\
\hline $1, V^{b}$ & $f \cdot b$ & 1 \\
\hline$r, f V^{a}$ & $19,9 \mathrm{~V}^{\mathrm{a}}$ & r \\
\hline
\end{tabular}

ستونهاى واجد حروف مشتر ك، در سطح احتمال ( p-value > 0.05 نفاوت معنىدارى ندارند.

There is no significant difference among those columns that have same letter.

كلو تاتيون احيا با غلظت r ميكرومول بر ليتر نسبت به ساير تر كيبات آنتىاكسيدانى از نظر تمايزيابى و توليد ساقهاى نويديد، نقش موثرترى داشت. تيمار هورمونى ه/ • ميلى گرم بر ليتر هورمون BAP به عنوان محيط كشت براى ساقهزيى كياه N. binaloudensis معرفى شده است (Nadjafi-Pour et al., 2016). در تحقيق حاضر مشخص سيط شد كشت ريزنمونه هاى متفاوت (بركى، ساقه مريستم رأس ساقه و هيبو كوتيل) در محيطهاى كشت مختلف (MS MS 1/2 و B5) حاوى ه/ • ميلى گرم بر ليتر هورمون BAP، مناسب ساقهزايى اين

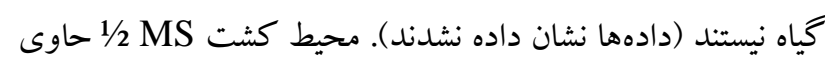
ه/ • ميلى گرم بر ليتر هورمون BAP داراى ساقهزايى ضعيفى بوده و اكثر ريزنمونهها در اين محيط كشت قهوهاى و نكروز شدند. يتانسيل ساقهزايى ضعيف و قهوهاى و نكروز شدن بافت ريزنمونه به دليل توليد تركيبات اكسيد كننده و تنش اكسيداتيو حاصل از اين Titov et al., ) تركيبات در بافت ريزنمونه مربوط مى 2006). احتمالا تركيبات آنتىاكسيدان باعث كاهش توليد

$$
\text { ريمارهاى هورمونى تحت بررسى معنى دار است (جدول Y). }
$$
نتايج تجزيه واريانس داده ها نشان داد كه، كاربرد غلظتهاى مختلف هورمون NAA تأثير معنى Nارى (p-value 0.05$)$ بر درصد ريشهزايى و ميانگين طول ريشهها دارد (جدول r). نتايج مقايسه ميانگين نشان داد كه، غلظت ب ميلى گرم بر ليتر NAA از بالاترين درصد ريشهزايى برخوردار هستند و تفاوت معنىدارى با ساير تيمارهاى بررسى شده داشت (جدول r). بيشترين طول ريشهها با مقدار Y M (سانتىمتر) به تيمار Y ميلى گرم در ليتر هورمون NAA

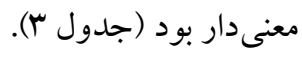

\footnotetext{
بحث

در اين مطالعه كاربرد تر كيبات آنتى اكسيدانى اسكوربيككاسيد و كلوتاتيون احيا، درصد باززايى و ساقهزايى را به صورت معنى الهي دارى (p-value ( 0.05 افزايش دادند. در اين بين كاربرد
} 
هورمون BAP B/ه ميلى گرم بر ليتر ديده شد. هورمون BAP در كياه (Ghanti et al., 2003) Mentha piperita L (Andrade \& Bosso, 2005) Lavandula dentate L. نيز بيشترين (Arikat et al., 2004) Salvia fruticose Mill. و تأثير را بر ميزان ساقهزايى داشت.

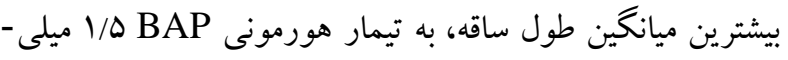

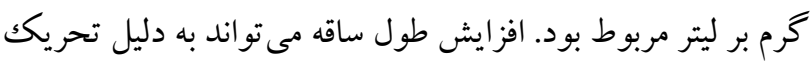

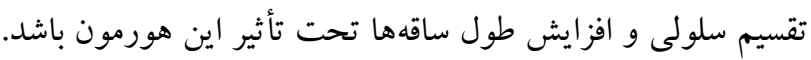

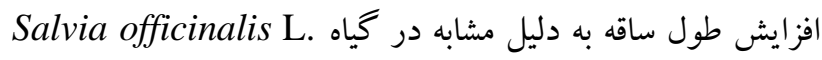
Thymus Pomel و (Tawfik \& Mohamed, 2007) نيز گزارش (Aicha \& Abdelmalek, 2014) bleicherianus

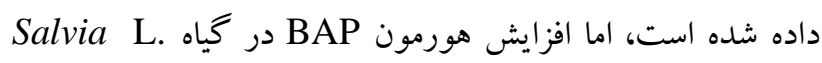
Ewa \& باعث كاهش رشد طولى ساقهها شد ( nemorosa .(Wysokinska, 2004 در ارتباط با اين موضوع، گزارش (Daniel et al., 2010) بر كياه Ocimum basilicum L نشان داد، بهترين تيمار هورمونى

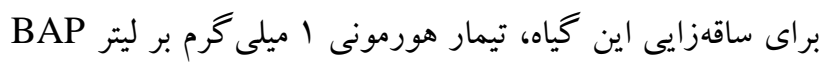

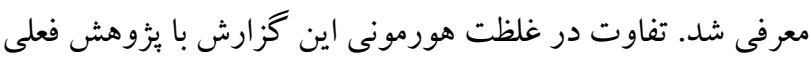

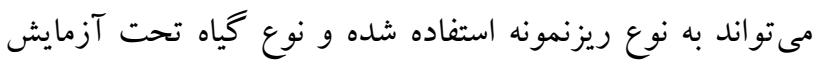

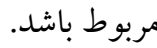
توان ريشهزايى در آمادهسازى ساقهها براى مرحله ساز گارى بـد

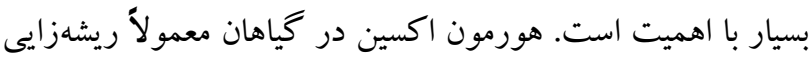

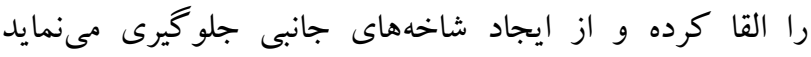

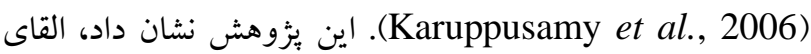
ريشه در ساقهاى نويديد به ميزان غلظت هورمون اكسين وابسته

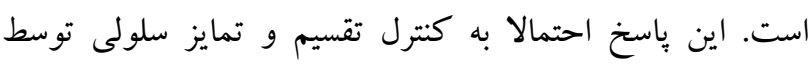

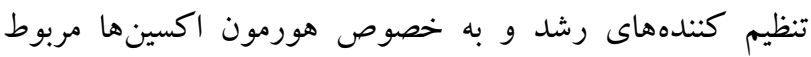
است. در گياهان مختلف، ميزان اكسين درونى در فرآيندهاى

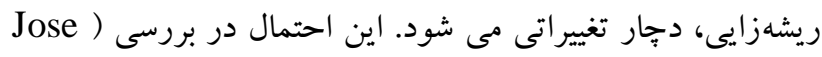
Alnus glutinosa L. روى تأييد شده است. (et al., 2012 در مطالعه حاضر، بيشترين درصد ريشهزايى و بلندترين طول ريشها به تيمار هورمونى NAA در غلظت ب ميلى گرم بر ليتر

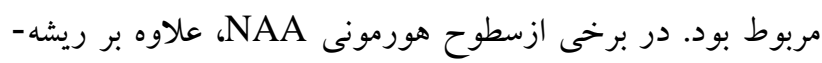

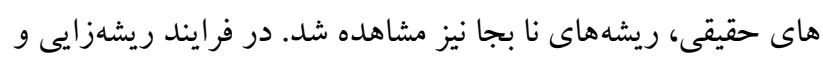

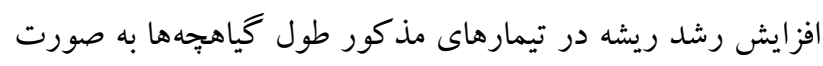

تركيبات سمى و فنلى در شرايط درون شيشه شده و از قهوهاى

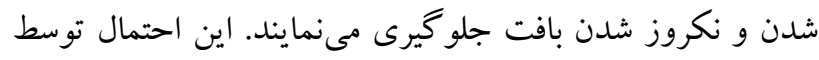

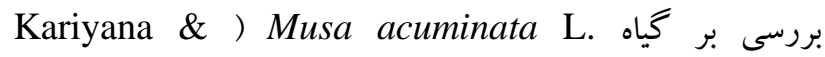
Eucalyptus camaldulensis و بر خياه (Nisyawati, 2013 تاييد شد. (Dibax et al., 2005) Dehnh. كاربرد آنتىاكسيدانهاى آسكوربيكاسيد و كلوتاتيون احيا براى افزايش تمايز ساقهاى گياهان در شرايط درون شيشه تأييد

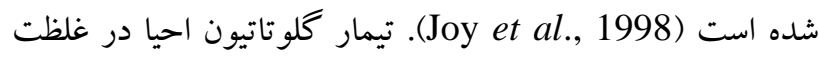

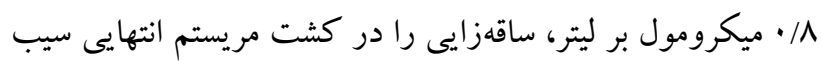

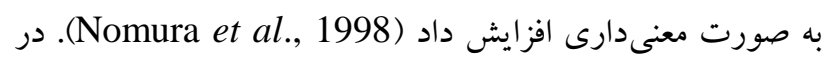

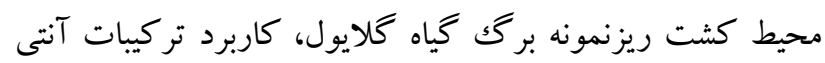
اكسيدان باعث تحريكك و افزايش ساقهزايى گياه شد (- Dutaa Gupta \& Datta, 2003

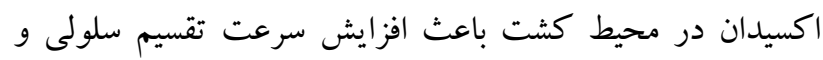

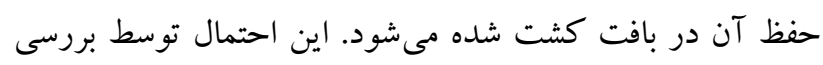
روى كشت سلول گياه تنباكو ( Nicotiana tabacum cv. De Pinto et al., ) تأييد شده است (Bright Yellow 2 2000). در بررسى كشت سلول كياه Arabidopsis thaliana فشخص شد كلوتاتيون احيا نقش تنظيمى بر ميزان (L.) Heynh فعاليت آنزيم (Poly ADP Ribose Polymerase) PARP دارد. فعاليت اين آنزيم با ميزان تقسيم سلولى ارتباط مستقيم دارد

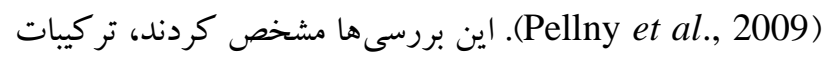

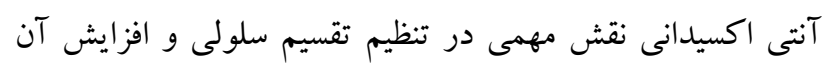

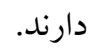

در آزمايش دوم غلظتهاى مختلف هورمون BAP در محيط

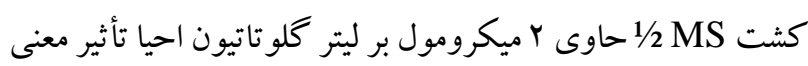

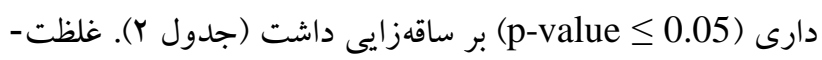
هاى مختلف هورمونهاى رشد در محيط القاى ساقه، اثر تنظيمى متفاوتى به روى مورفورنز دارند. كاربرد خارجى غلظتهاى

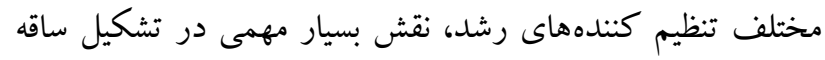
دارند وشديداً بر ساقهزايى تأثير گذذار هستند (Rout, 2000).

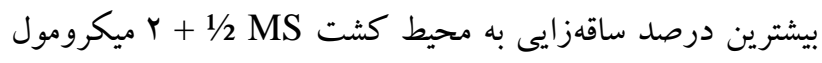

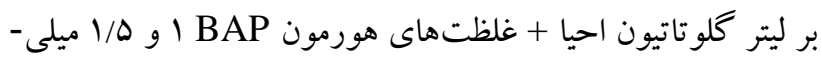
كرم بر ليتر مربوط بود. همجنين بيشترين تعداد ساقه توليد شده درد

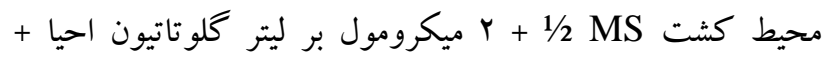




\section{REFERENCES}

Aicha, N. and Abdelmalek, E. 2014. In vitro regeneration and clonal multiplication of Thymus bleicherianus Pomel, a rare and threatened medicinal and aromatic in Morocco. - J. Med. Aromat. Plants 3: 145.

Aliyo, O.M. 2005. Application of tissue culture to cashew (Anacardium occidentale) breeding: an appraisal. AJB 4: 1485-1489.

Andrade, L. and Basso, R. 2005. Micropropagation of Lavandula dentata from axillary buds of field-grown adult plants. - Biol. Plantarum 3: 439-442.

Arikat, N.A, Javad F.M., Karam, N.S. and Shilbi, R.A. 2004. Micropropagatin and accumulation of essential oil in wild sage (Salvia fruticosa Mill.). - Sci. Hortic. 100: 193-202.

Arnon, D. and Hoagland, D. 1940. Crop production in artificial culture solutions in soils with special reference to factors influencing yields and absorption of inorganic nutrients. - J. Soil Sci. 50: 463-485.

Daniel, A., Kalidass, C. and Mohan, V.R. 2010. In vitro multiple shoot induction through axillary bud of Ocimum basilicum L. an important medicinal plant. IJBT 5: 24-28.

De Pinto, M.C., Tommasi, F. and De Gara, L. 2000. Enzymes of the ascorbate biosynthesis and ascorbateglutathione cycle in cultured cells of tobacco Bright Yellow 2. - Plant Physiol. Biochem. 38: 541-550.

Dibax, R., Eisfeld, C., Chuquel, F., Koehler, H. and Quoirin, M. 2005. Plant regeneration from cotyledonary explants of Eucalyptus camalduensis. Sci. Agricola. 62: 406-412.

Dutta Gupta, S. and Datta, S. 2003. Antioxidant enzyme activities during in vitro morphogenesis of gladiolus and the effect of application of antioxidants on plant regeneration. - Biol. Plant 47: 179-183.

Ewa, S., and Wysokinska, H. 2004. In vitro regeneration of Salvia nemerosa L. from shoot tips and leaf explants. - In vitro Cell Dev. Biol. Plant. 40: 596-602.

Ghahreman, A. 1999. Biodiversity of Plants in Iran. Tehran University, Iran Synder. R.L. (1985). Hand calculating degree-days. - J. Agri. Meteoy. 35: 353358.

Ghannadi, A., Aghazari, F., Mehrabani, M., Mohagheghzadeh, A. and Mehregan, I. 2003. Quantity and comp-osition of the SDE prepared essential oil of Nepeta macrosiphon Bioss. - Iran. J. Pharm. Res. 2: 5-103.

Ghanti, K., Kaviraj, C.P., Venugopal, R.P., Jabeen, F.T.Z. and Rao, S. 2003. Rapid regeneration of Mentha piperita L. of shoot tip and nodal explant. IBJT 5: 594-598.

Jamzad, Z. 2012. Lamiaceae. - In: Assadi, M. et al. (eds.): Flora of Iran, No. 76. - RIFR, Tehran. 1066 pp.

Jose, M.C.S., Romero, L. and Janeiro, L.V. 2012. Effect of Indole-3-Butyric Acid on root formation in Alnus glutinosa. - Silva Fenn. 46: 643-654.

Joy, R.W., Patel, K.R. and Thorpe, T.A. 1988. Ascorbic acid enhancement of organogenesis in tobacco callus. - PCTOC 13: 219-22.

Kariyana, K. and Nisyawati, N. 2013. Effect of ascorbic acid, activated carbon and light duration on explant

$$
\begin{aligned}
& \text { قابل توجهى افزايش يافت كه اين موضوع احتمالاً به اثر مثبت ريشه } \\
& \text { بر بقاى گياهجه ها در مراحل بعدى مربوط است است. }
\end{aligned}
$$

Salvia fruticosa بررسىهاى انجام يافته روى ريشهزايى كياه نشان داد، اكسينها نقش مهمى در القاى ريشه اين گياهان برعهده دارند (Arikat et al., 2004). در اين آزمايش مؤثرترين هورمون براى ريشهزايى كياه .Salvia broussonetii Benth، هورمون

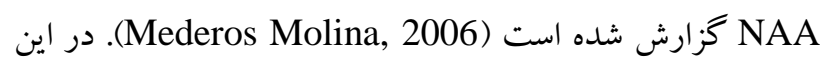
آزمايش بهترين تيمار براى ريشهزايى ساقهاى توليد شده از جوانه هاى انتهايى كياه . Salvia lerifoliia Benth محيط كشت حاوى ا ميلى گرم بر ليتر IBA بود (Modarres et al., 2012).

$$
\begin{aligned}
& \text { نتيجحه تيرى } \\
& \text { نتايج به دست آمده بيانكر اين بود كه تيمار Y ميكرومول بر ليتر }
\end{aligned}
$$

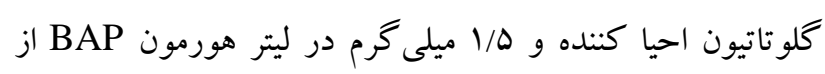

$$
\begin{aligned}
& \text { مفيدترين و كار آمدترين تنظيم كنندهاى رشد ساقهزايى اين كياه }
\end{aligned}
$$

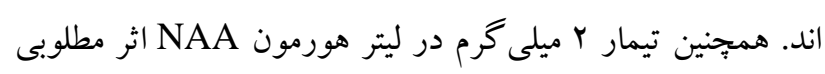

$$
\begin{aligned}
& \text { بر ريشهزايى ساقه هاى نويديد گياه بونه ساى بينالودى داشت. } \\
& \text { سياسگز ارى } \\
& \text { اين بززوهش توسط معاونت بزوهش و فناورى دانشگاه فردوسى }
\end{aligned}
$$

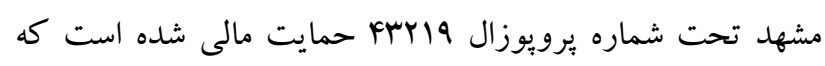

$$
\begin{aligned}
& \text { بدينوسيله قدردانى مى گردد. }
\end{aligned}
$$


browning of banana cultivar barangan (Musa acuminata L.) in vitro culture. - IJRRAS 16: 118-123.

Karuppusamy, S., Kiranmai, C., Aruna, V. and Pullaiah, T. 2006. Micropropagation of Vanasushava pedata. An endangered medicinal plant of South India. BAPTCB 16: 85-94.

Mederos Molina, S. 2006. Micropropagation of Salvia broussonetii Benth. a medicinal plant species. BAPTCB 16: 19-23.

Modarres, M., Lahouti, M., Gangeali, A. and Asili, J. 2012 Study of micropropagation of Salvia lerifolia Benth. using shoot tip. - J. Plant Biol. 4: 89-100.

Murashige, T., and Skoog, F.A. 1962. A revised medium for rapid growth and bioassays with tobacco tissue cultures. - Plant Physiol. 15: 473-479.

Nadjafi-Pour, N., Valizadeh, M., Mostafavi, E. and Maassomi, A.A. 2016. Micro propagation study of Nepeta binaloudensis Jamzad in vitro culture. International conference on new horizon of biology in agricultural Science. Tehran, Society of Modern Science and Technology.

Nadjafi, F., Koocheki, A., Honermeier, B. and Asili, J. 2009. Autecology, Ethnomedicinal and phytochemical studies of Nepeta binaloudensis Jamzad a highly endangered medicinal plant of Iran. J. Essent. Oil Bear Plant 12: 37-41.

Nomura, K., Matsumoto, S., Masuda, K. and Inoue, M. 1998. Reduced glutathione promotes callus growth and shoot development in a shoot tip culture of apple stock. - Plant Cell Rep. 17: 597-600.

Pei, S. 2001. Ethnobotanical approaches of traditional medicine studies: some experiences from Asia. Pharm. Biol. 39: 74-79.
Pellny, T.K., Locato, V., Vivancos, P.D., Markovic, J., De Gara, L., Pallardó, F.V. and Foyer, C.H. 2009. Pyridine nucleotide cycling and control of intracellular redox state in relation to poly (ADPribose) polymerase activity and nuclear localization of glutathione during exponential growth of Arabidopsis cells in culture. - Mol. Plant 2: 442456.

Rout, G.R. 2000. In vitro manipulation and propagation of medicinaplants. - Biotechnol. Adv. 18: 91-120.

Rustaiyan, A. and Nadji, K. 1999. Composition of the essential oils of Nepeta isphanica Boiss and Nepeta binaloudensis Jamzad from Iran. - Flavour Fragr. J. 35-37.

Skala, A. and Wysokinska, A. 2006. In vitro Regeneration of (Salvia nemorosa L.) from shoot tips and leaf explants. - In Vitro Cell Dev. Biol. Plant 1: 90-151.

Sulistiarini, D.L. 1999. Ocimum gratissimum L. In: A. P. L. Oyen and D. X. Nguyen, Eds. Plant Resources of South- East Asia No. 19: Essential Oils Plants. Prosea Foundation, Bogor. 140-142.??

Tawfik, A. A., and Mohamed M.F. 2007. Regeneration of Salvia officinalis L. via induction of meristematic callus. - In Vitro Cell Devel. Biol. Plant 43: 21-27.

Titov, S., Bhowmik, S., Mandal, A., Alam, M. and Nasir, A. 2006. Control of phenolic compound secretion and effect of growth regulators for organ formation from Musa spp. cv. Kanthali floral bud explants. - Am. J. Biochem. Biotech. 2: 97-104.

How to cite this article:

Sagharyan, M., Ganjeali, A. and Cheniany, M. 2019. Investigating the effect of antioxidant compounds and various concentrations of BAP and NAA on the improvement of in vitro stem and root formation of Nepeta binaloudensis Jamzad. - Nova Biol. Reperta 6: 198-205.

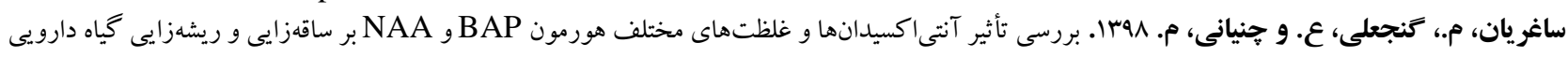

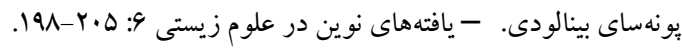

